\title{
Article
}

\section{A family level rDNA based phylogeny of Cucurbitariaceae and Fenestellaceae with descriptions of new Fenestella species and Neocucurbitaria gen. nov.}

\author{
Wanasinghe $\mathrm{DN}^{1,2,3}$, Phookamsak $\mathrm{R}^{1,2,3}$, Jeewon $\mathrm{R}^{4}$, Wen Jing $\mathbf{L i}^{1,2,3}$, Hyde \\ $\mathrm{KD}^{1,2,3,5}$, Jones $\mathrm{EBG}^{5}$, Camporesi $\mathrm{E}^{6,7}$ and Promputtha $\mathrm{I}^{8 *}$
}

${ }^{1}$ World Agro Forestry Centre, East and Central Asia, 132 Lanhei Road, Kunming 650201, Yunnan China

${ }^{2}$ Key Laboratory for Plant Biodiversity and Biogeography of East Asia (KLPB), Kunming Institute of Botany, Chinese Academy of Science, Kunming 650201, Yunnan China

${ }^{3}$ Center of Excellence in Fungal Research, Mae Fah Luang University, Chiang Rai, 57100, Thailand

${ }^{4}$ Department of Health Sciences, Faculty of Science, University of Mauritius, Reduit, Mauritius

${ }^{5}$ Nantgaredig, 33B St. Edwards Road, Southsea, Hants., PO5 3DH, UK

${ }^{6}$ Società per gli Studi Naturalistici della Romagna, C.P. 144, Bagnacavallo (RA), Italy

${ }^{7}$ A.M.B. Gruppo Micologico Forlivese "Antonio Cicognani”, Via Roma 18, Forli, Italy; A.M.B. Circolo Micologico

"Giovanni Carini”, C.P. 314, Brescia, Italy

${ }^{8}$ Department of Biology, Faculty of Science, Chiang Mai University, Chiang Mai 50200, Thailand

Wanasinghe DN, Phookamsak R, Jeewon R, Wen Jing Li, Hyde KD, Jones EBG, Camporesi E, Promputtha I 2017 - Fenestellaceae with descriptions of new Fenestella species and Neocucurbitaria gen. nov. Mycosphere 8(1), 397-414, Doi 10.5943/mycosphere/8/4/2

\begin{abstract}
The taxonomy of the family Cucurbitariaceae and its allies, especially Fenestellaceae has received little attention despite its broad relevance. To further clarify phylogenetic relationships between the two families, new collections were made and samples examined morphologically. Morphometric observations reveal two new Fenestella species that are different from other known species and are introduced as Fenestella ostryae sp. nov. and F. mackenziei sp. nov. The asexual morph of $F$. ostryae is also established from single spore cultures and described. Phylogeny inferred from a combined dataset of ITS, LSU and SSU rDNA sequence also reveals a close association of the new taxa to $F$. fenestrata, but they are distinct. Sequence analyses also support our previous assumption that Fenestellaceae should be synonymized with Cucurbitariaceae. Pyrenochaeta quercina, Pyrenochaeta unguis-hominis and an additional new cucurbitaria-like isolate constitute a strongly supported monophyletic lineage within Cucurbitariaceae. To better resolve intergeneric level relationships and improve taxonomic issues within Cucurbitariaceae, a new genus, Neocucurbitaria gen. nov. is introduced with Neocucurbitaria acerina as a new species.
\end{abstract}

Key words - Asexual morph - Dictyospores - Dothideomycetes - Italy - phylogeny - sexual morph

\section{Introduction}

The family Cucurbitariaceae is a well-supported monophyletic family in the order Pleosporales (Doilom et al. 2013, Hyde et al. 2013, Wijayawardene et al. 2014, Li et al. 2016). The family was introduced by Winter (1885) and typified by Cucurbitaria berberidis. Cucurbitariaceae 
is characterized by aggregated, ostiolate ascomata, which are seated on a basal stromatic structure, fissitunicate and cylindrical asci, pigmented, phragmosporous or muriform ascospores and a necrotrophic or saprobic lifestyle on woody plants (Hyde et al. 2013). Intergeneric classification based on phenotypes within Cucurbitariaceae has often been controversial. For example, Barr (1987) considered 'turbinate or globose or ovoid ascomata, with warted or nearly smooth surfaces, cylindrical or slightly clavate or oblong asci, symmetric and ellipsoid or fusoid or asymmetric and oblong or elongate ascospores' as general features of Cucurbitariaceae and considered the family to belong in Pleosporales. Considering the above phenotypic features, genera such as Cucurbitaria, Cucurbidothis, Otthia, Rhytidiella and Syncarpella were also included in the family. Later phylogenetic studies have shown that Cucurbitariaceae is a heterogeneous group and recent studies have excluded some genera from this family and referred other genera to the family (see the notes under Cucurbitariaceae in Hyde et al. 2013 and Doilom et al 2013).

Doilom et al. (2013) revisited the family Cucurbitariaceae based on DNA sequence data in databases to verify its phylogenetic affinities, examination of type species and links to asexual morphs. They epitypified Cucurbitaria berberidis with molecular data and a pyrenochaeta-like asexual morph, illustrated Curreya, Rhytidiella and Syncarpella from their holotypes and discussed their familial affinities. Hyde et al. (2013) also provided a comprehensive transcript to this family with illustrations. Wijayawardene et al. (2014) included Cucurbidothis, Cucurbitaria, Curreya, Pyrenochaeta, Pyrenochaetopsis, Rhytidiella and Syncarpella as conventional genera in Cucurbitariaceae. However, Cucurbitariaceae members still comprise a large number of epithets in Index Fungorum (Doilom et al. 2013) and only a small number of species have DNA sequence data in GenBank. Thambugala et al. (2015) have introduced a new genus, Neocurreya for Curreya austroafricana, $C$. grandicipis and $C$. proteae in Floricolaceae (Pleosporales) based on evidence from morphology and phylogeny. The placement of the type species of Curreya, C. conorum is still unclear as the latter has not yet been cultured and there is no DNA sequence data in databases to verify their phylogenetic affinities. In addition, DNA sequence is also unavailable for species of Cucurbidothis, Rhytidiella and Syncarpella. The taxonomy of these similar and closely related genera warrants further investigations based on fresh collections and phylogenetic inferences.

We have recently revisited the taxonomy of various members of pleosporaceous Dothideomycetes, with the intention of providing a better understanding of their phylogeny based on both morphology and multi-gene phylogenetic analyses. During collections and examination, we have isolated taxa from Italy which belong to the Cucurbitariaceae based on our preliminary phylogenetic analyses. Subsequently, with further morphological and molecular characterization, we present an account of a new genus, Neocucurbitaria and rectify the familial placement of Fenestella with two new species. The new taxa are compared with other species in Cucurbitariaceae and comprehensive descriptions and micrographs are provided and supported with DNA based phylogenies.

\section{Materials \& Methods}

\section{Sample collection, morphological studies and isolation}

Fresh fungal material was collected from Forlì-Cesena Province in Italy and brought to the laboratory in Zip lock plastic bag. Samples were examined with a Motic SMZ 168 Series microscope. Hand sections of the fruiting structures were mounted in water for microscopic studies and photomicrography. The taxa were examined using a Nikon ECLIPSE 80i compound microscope and photographed with a Canon 550D digital camera fitted to the microscope. Indian ink was added to water mounts to show the presence of a gelatinous sheath around the ascospores. Measurements were made with the Tarosoft (R) Image Frame Work program and images used for figures processed with Adobe Photoshop CS3 Extended version 10.0 software (Adobe Systems, USA).

Single ascospore isolation was carried out following the method described in Chomnunti et al. (2014). Germinated spores were individually transferred to potato dextrose agar (PDA) plates 
and grown at $16^{\circ} \mathrm{C}$ in the daylight. Colony colour and other characters were observed and measured after three weeks. The specimens are deposited at the Mae Fah Luang University (MFLU) Herbarium, Chiang Rai, Thailand. Living cultures are deposited at the Culture Collection of Mae Fah Luang University (MFLUCC). Faces of Fungi and Index Fungorum numbers are provided as outlined in Jayasiri et al. (2015) and Index Fungorum (2017) and new species are justified based on recommendations outlined by Jeewon \& Hyde (2016).

\section{DNA extraction and PCR amplification}

Fungal isolates were grown on PDA for 3-4 weeks at $25^{\circ} \mathrm{C}$ and total genomic DNA was extracted from 50 to $100 \mathrm{mg}$ of axenic mycelium scraped from the edges of the growing culture (Wu et al. 2001; Jeewon et al. 2002). Mycelium was ground to a fine powder with liquid nitrogen and DNA was extracted using the Biospin Fungus Genomic DNA Extraction Kit-BSC14S1 (BioFlux, P.R. China) following the instructions of the manufacturer. DNA to be used as template for PCR were stored at $4{ }^{\circ} \mathrm{C}$ for use in regular work and duplicated at $-20{ }^{\circ} \mathrm{C}$ for long term storage.

DNA sequence data was obtained from the partial sequences of three genes, the internal transcribed spacers (ITS1, 5.8S, ITS2), large subunit (28S, LSU) and small subunit rDNA (18S, SSU). ITS regions were amplified using primers ITS5 (5'-GGAAGTAAAAGTCGTAACAAGG-3') and ITS4 (5'-TCCTCCGCTTATTGATATGC-3') (White et al. 1990). LSU was amplified using the primers LROR (5'-TCCTGAGGGAAACTTCG-3') and LR5 (5'-ACCCGCTGAACTTAAGC-3') (Vilgalys \& Hester 1990, Rehner \& Samuels 1994). SSU was amplified using primers NS1 (5'GTAGTCATATGCTTGTCTC-3') and NS4 (5'-CTTCCGTCAATTCCTTTAAG-3') (White et al. 1990).

Polymerase chain reaction (PCR) was carried out in a volume of $25 \mu$ which contained 12.5 $\mu 1$ of $2 \times$ Power Taq PCR MasterMix (Bioteke Co., China), $1 \mu l$ of each primer $(10 \mu \mathrm{M}), 1 \mu \mathrm{l}$ genomic DNA and $9.5 \mu \mathrm{l}$ deionized water. PCR thermal cycle program for gene amplifications were as follows: initialization at $95{ }^{\circ} \mathrm{C}$ for 5 mins, followed by 35 cycles of denaturation at $95{ }^{\circ} \mathrm{C}$ for $90 \mathrm{~s}$, annealing at $55^{\circ} \mathrm{C}$ (ITS and LSU) and $48{ }^{\circ} \mathrm{C}$ (SSU) for $1 \mathrm{~min}$., elongation at $72{ }^{\circ} \mathrm{C}$ for 1 min. and final extension at $72{ }^{\circ} \mathrm{C}$ for 10 mins. PCR amplicons was verified on $1 \%$ agarose electrophoresis gels stained with ethidium bromide. The amplified PCR fragments were sent to a commercial sequencing provider (BGI, Ltd Shenzhen, P.R. China). The nucleotide sequence data acquired were deposited in GenBank (Table 1).

\section{Sequencing and sequence alignment}

Other sequences used in the analyses (Table 1) were obtained from GenBank based on blast searches in GenBank and published data (de Gruyter et al. 2010, Doilom et al. 2013, Ariyawansa et al. 2015, Crous et al. 2015). The multiple alignments of all sequences, as well as the reference sequences were automatically generated with MAFFT v. 7 (http://mafft.cbrc.jp/alignment/ server/index.html; Katoh \& Standley 2013), and were improved manually when necessary using BioEdit v. 7.0.5.2 (Hall 1999). Ambiguous regions were excluded from the analyses and gaps were treated as missing data.

\section{Phylogenetic analysis}

Phylogenetic analyses of both individual and combined aligned data were performed under maximum-likelihood, maximum parsimony and Bayesian criteria. The sequence alignments were converted to NEXUS file (. nex) for maximum parsimony and Bayesian analyses using ClustalX2 v. 1.83 (Thompson et al. 1997). The NEXUS file was prepared for MrModeltest v. 2.2 after deleting the symbols ="ABCDEFGHIKLMNOPQRSTUVWXYZ" (Nylander 2004) in PAUP (Phylogenetic Analysis Using Parsimony) v. 4.0b10 (Swofford 2002). For the Randomized Accelerated Maximum Likelihood (RAxML) analysis, sequence alignments were converted to PHYLIP file (. phy) using ALTER (alignment transformation environment: http://sing.ei.uvigo.es/ALTER/; 2016). 
Parsimony analysis was carried with the heuristic search option in PAUP v. $4.0 \mathrm{~b} 10$ with the following parameter settings: characters unordered with equal weight, random taxon addition, branch swapping with tree bisection-reconnection (TBR) algorithm, branches collapsing if the maximum branch length was zero. Alignment gaps were treated as missing characters in the analysis of the combine data set, where they occurred in relatively conserved regions. Trees were inferred using the heuristic search option with 1000 random sequence additions, with maxtrees set at 5000. Descriptive tree statistics for parsimony; Tree Length (TL), Consistency Index (CI), Retention Index (RI), Relative Consistency Index (RC) and Homoplasy Index (HI) were calculated for trees generated under different optimality criteria. The Kishino-Hasegawa tests (Kishino \& Hasegawa 1989) were performed in order to determine whether trees were significantly different. Maximum parsimony bootstrap values (MP) equal or greater than $75 \%$ are given above each node (Fig. 1). Other details pertaining to analyses (e.g. consideration of TT ratios, comparison of tree topologies, selection of outgroups etc.) are outlined in Jeewon et al. (2003, 2004, 2013).

The evolutionary models for Bayesian analysis and maximum-likelihood were selected independently for each locus using MrModeltest v. 2.3 (Nylander 2004) under the Akaike Information Criterion (AIC) implemented in PAUP v. 4.0b10. GTR+I+G model is resulted in each locus for Bayesian analysis and maximum-likelihood by AIC in MrModeltest as the best-fit model.

Bayesian analysis was conducted with MrBayes v. 3.1.2 (Huelsenbeck \& Ronqvist 2001) to evaluate Bayesian posterior probabilities (BYPP) (Rannala \& Yang 1996; Zhaxybayeva \& Gogarten 2002) by Markov Chain Monte Carlo sampling (BMCMC). Six simultaneous Markov chains were run for 5,000,000 generations and trees were sampled every 1000th generation. The distribution of log-likelihood scores was examined to determine stationary phase for each search and to decide if extra runs were required to achieve convergence, using the program Tracer 1.5 (Rambaut \& Drummond 2007). First $20 \%$ of generated trees were discarded and remaining $80 \%$ of trees were used to calculate posterior probabilities of the majority rule consensus tree.

Maximum likelihood trees were generated using the RAxML-HPC2 on XSEDE (8.2.8) (Stamatakis 2008, 2014) in the CIPRES Science Gateway platform (Miller et al. 2010). Maximum likelihood bootstrap values (ML) equal or greater than $75 \%$ are given above each node (Fig. 1).

Phylograms were visualized with FigTree v1.4.0 program (Rambaut 2012) and reorganized in Microsoft power point (2007) and Adobe Illustrator ${ }^{\circledR}$ CS5 (Version 15.0.0, Adobe ${ }^{\circledR}$, San Jose, CA). The finalized alignment and tree were deposited in TreeBASE, submission ID: 20603 (http://www.treebase.org/).

\section{Results and Discussion}

\section{Phylogenetic analysis}

The combined LSU, SSU and ITS gene dataset comprised 55 sequences with strains from Cucurbitariaceae and our new strains. After exclusion of ambiguous regions, the combined dataset included 2293 positions (LSU: 1-850; SSU: 851-1808; ITS: 1809-2293) including gaps. RAxML analysis yielded a best scoring tree (Fig. 1) with a final ML optimization likelihood value of 6683.634221. The matrix had 335 distinct alignment patterns, with $23.06 \%$ of undetermined characters or gaps. Estimated base frequencies were as follows; $\mathrm{A}=0.253143, \mathrm{C}=0.212693, \mathrm{G}=$ $0.281258, \mathrm{~T}=0.252906$; substitution rates $\mathrm{AC}=0.424225, \mathrm{AG}=1.978950, \mathrm{AT}=5.795696, \mathrm{CG}=$ 5.267144, $\mathrm{CT}=13.194889, \mathrm{GT}=1.000$; proportion of invariable sites $\mathrm{I}=0.794639$; gamma distribution shape parameter $\alpha=0.647201$. The maximum parsimonious dataset consists of 2018 constant characters, 233 parsimony-informative and 42 parsimony-uninformative characters. The parsimony analysis of the data matrix resulted in five thousand equally parsimonious trees with a length of 650 steps $(\mathrm{CI}=0.575, \mathrm{RI}=0.788, \mathrm{RC}=0.454, \mathrm{HI}=0.425)$ in the first tree. The Bayesian and MP trees recovered did not contradict the ML tree topology for the strongly supported branches of the combined gene data set and hence only the ML tree is shown (Fig. 1).

In this study, we have included taxa representing all Cucurbitariaceae genera which are available in GenBank (Fig. 1). Cucurbitaria elongata (AFTOL-ID 1568, MFLUCC 14-0260) and 


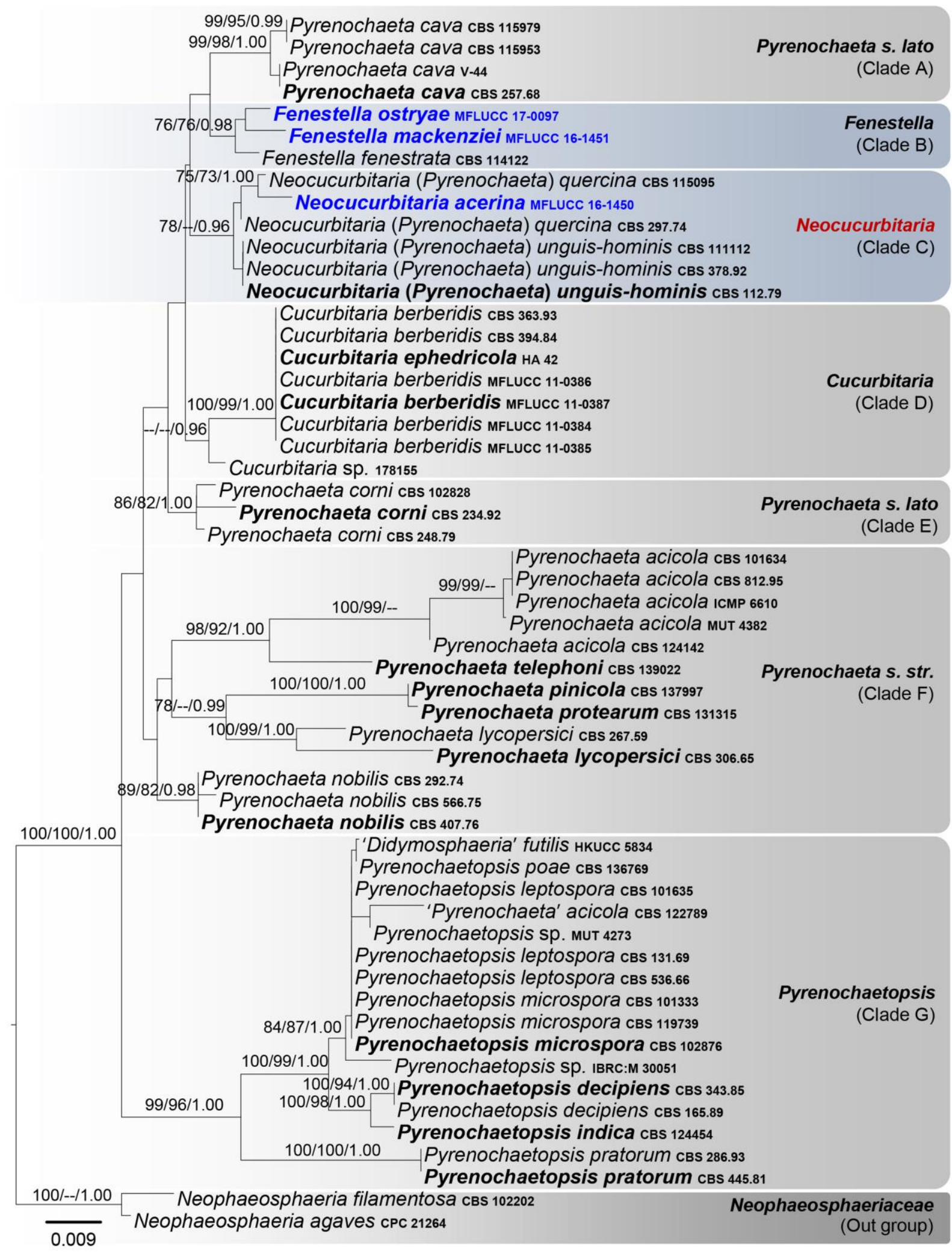

Fig. 1 - RAxML tree based on analysis of a combined dataset of LSU, SSU and ITS partial sequence data. Bootstrap support values for ML, MP higher than $75 \%$ and BYPP greater than 0.95 are given above each branch respectively. The ex-type and reference strains are in bold. The new isolates are in blue. The tree is rooted to Neophaeosphaeria agaves and $N$. filamentosa (Neophaeosphaeriaceae).

Pyrenochaeta romeroi (CBS 252.60, CBS 122784) did not group with members of Cucurbitariaceae in Pleosporinae (data not shown). Thus, we excluded them from the final data set. 
Table 1 Taxa used in the phylogenetic analysis and their corresponding GenBank numbers. The newly generated sequences are indicated in bold.

\begin{tabular}{|c|c|c|c|c|}
\hline \multirow{2}{*}{ Taxon } & \multirow{2}{*}{$\begin{array}{l}\text { Culture accession } \\
\text { no. }\end{array}$} & \multicolumn{3}{|c|}{ GenBank accession no.* } \\
\hline & & ITS & LSU & SSU \\
\hline Cucurbitaria berberidis & CBS 363.93 & JF740191 & GQ387606 & GQ387545 \\
\hline C. berberidis & CBS 394.84 & NA & GQ387605 & GQ387544 \\
\hline C. berberidis & MFLUCC 11-0384 & NA & KC506793 & KC506797 \\
\hline C. berberidis & MFLUCC 11-0385 & NA & KC506794 & KC506798 \\
\hline C. berberidis & MFLUCC 11-0386 & NA & KC506795 & KC506799 \\
\hline C. berberidis & MFLUCC 11-0387 & NA & KC506796 & KC506800 \\
\hline C. ephedricola & HA 42 & NA & KT313007 & KT313005 \\
\hline Cucurbitaria sp. & 178155 & NA & FJ215698 & FJ215704 \\
\hline Didymosphaeria futilis & HKUCC 5834 & NA & GU205219 & GU205236 \\
\hline Fenestella fenestrata & CBS 114122 & NA & GU205220 & GU205238 \\
\hline Fenestella mackenziei & MFLUCC 16-1451 & KY563071 & KY563074 & KY563077 \\
\hline F.ostryae & MFLUCC 17-0097 & KY563072 & KY563075 & KY563078 \\
\hline Neocucurbitaria acerina & MFLUCC 16-1450 & KY563073 & KY563076 & KY563079 \\
\hline N. (Pyrenochaeta) quercina & CBS 115095 & NA & GQ387619 & GQ387558 \\
\hline N. (Pyrenochaeta) quercina & CBS 297.74 & NA & GQ387620 & GQ387559 \\
\hline N. (Pyrenochaeta) unguis-hominis & CBS 111112 & NA & GQ387623 & GQ387562 \\
\hline N. (Pyrenochaeta) unguis-hominis & CBS 112.79 & NA & GQ387622 & GQ387561 \\
\hline N. (Pyrenochaeta) unguis-hominis & CBS 378.92 & EU930010 & GQ387621 & GQ387560 \\
\hline Neophaeosphaeria agaves & CPC 21264 & $\begin{array}{l}\text { NR_13783 } \\
3\end{array}$ & KF777227 & NA \\
\hline N. filamentosa & CBS 102202 & JF740259 & GQ387577 & GQ387516 \\
\hline Pyrenochaeta acicola & CBS 101634 & NA & GQ387603 & GQ387542 \\
\hline P. acicola & CBS 122789 & NA & EU754204 & EU754105 \\
\hline P. acicola & CBS 124142 & NA & GQ387604 & GQ387543 \\
\hline P. acicola & CBS 812.95 & NA & GQ387602 & GQ387541 \\
\hline P. acicola & ICMP 6610 & KT309953 & KT309741 & NA \\
\hline P. acicola & MUT 4382 & KJ395501 & KJ395497 & NA \\
\hline P. cava & CBS 115953 & NA & GQ387607 & GQ387546 \\
\hline P. cava & CBS 115979 & AY853248 & EU754198 & EU754099 \\
\hline P. cava & CBS 257.68 & JF740260 & EU754199 & EU754100 \\
\hline P. cava & $\mathrm{V}-44$ & NA & KF590167 & NA \\
\hline P. corni & CBS 102828 & NA & GQ387609 & GQ387548 \\
\hline P. corni & CBS 234.92 & NA & EU754176 & EU754077 \\
\hline P. corni & CBS 248.79 & NA & GQ387608 & GQ387547 \\
\hline P. lycopersici & CBS 267.59 & JF740261 & GQ387612 & GQ387551 \\
\hline P. lycopersici & CBS 306.65 & $\begin{array}{l}\text { NR_10358 } \\
1\end{array}$ & EU754205 & EU754106 \\
\hline P. nobilis & CBS 292.74 & NA & GQ387615 & GQ387554 \\
\hline P. nobilis & CBS 407.76 & EU930011 & EU754206 & EU754107 \\
\hline P. nobilis & CBS 566.75 & NA & GQ387616 & GQ387555 \\
\hline P. pinicola & CPC 23455 & KJ869152 & KJ869209 & $\mathrm{NA}$ \\
\hline P. protearum & CBS 131315 & JQ044434 & JQ044453 & NA \\
\hline P. telephoni & CBS 139022 & KM516291 & KM516290 & KR260987 \\
\hline Pyrenochaetopsis decipiens & CBS 165.89 & NA & GQ387625 & GQ387564 \\
\hline P. decipiens & CBS 343.85 & NA & GQ387624 & GQ387563 \\
\hline$P$. indica & CBS 124454 & NA & GQ387626 & GQ387565 \\
\hline P. leptospora & CBS 101635 & JF740262 & GQ387627 & GQ387566 \\
\hline P. leptospora & CBS 131.69 & NA & GQ387629 & GQ387568 \\
\hline P. leptospora & CBS 536.66 & NA & GQ387628 & GQ387567 \\
\hline
\end{tabular}




\begin{tabular}{lllll} 
P. microspora & CBS 101333 & NA & GQ387630 & GQ387569 \\
P. microspora & CBS 102876 & NA & GQ387631 & GQ387570 \\
P. microspora & CBS 119739 & NA & GQ387632 & GQ387571 \\
$\begin{array}{l}\text { P. poae } \\
\text { P. pratorum }\end{array}$ & CBS 136769 & KJ869117 & KJ869175 & NA \\
$P$. pratorum & CBS 286.93 & JF740264 & JF740331 & NA \\
Pyrenochaetopsis sp. & CBS 445.81 & NR_11162 & GU238136 & GU238228 \\
Pyrenochaetopsis sp. & IBRC:M 30051 & KF730241 & KF803343 & KF803344 \\
\hline
\end{tabular}

*NA: No sequence available in GenBank.

All Pyrenochaeta cava strains analyzed herein (CBS 115979, CBS 115953, CBS 257.68 and V-44) cluster in a highly supported monophyletic clade (99\% ML / 98\% MP / 1.00 BYPP, clade A, Fig 1) in Cucurbitariaceae. Fenestella species analyzed here also constitute a clade (clade B) with $76 \%$ ML / 76\% MP / 0.98 BYPP (Fig. 1). Fenestella fenestrata (CBS 114122) is basal to F. ostryae MFLUCC 16-1451 and F mackenziei MFLUCC 16-0184 which are new taxa in this study.

Pyrenochaeta quercina (CBS 297.74, CBS 115095), P. unguis-hominis (CBS 112.79, CBS 378.92, CBS 111112) and our new strain (MFLUCC 16-1450) grouped in a separate clade (clade C) with $78 \%$ ML and 0.96 BYPP, but with $>75 \%$ in MP analysis. The sexual morph of Pyrenochaeta is understudied and the phylogenetic affiliation of Neocucurbitaria with one of the Pyrenochaeta quercina (asexual morph) strains (CBS 115095) in this subclade is particularly interesting. The subclade is significantly supported in all statistical analyses in this study (75\% ML / 73\% MP / 1.00 BYPP, Fig 1). However, DNA sequence data of P. quercina (CBS 115095) analysed herein is an unverified sequence as it is not from the type material. Given that the relationship between the two taxa is undetermined, we introduce our isolate as a new species (Neocucurbitaria acerina) in clade C (Fig. 1). Given the phylogenetic results obtained herein with Pyrenochaeta in clade $\mathrm{C}$, we believe that it would taxonomically more appropriate to establish a new genus, Neocucurbitaria to accommodate these species.

The strains of the type genus (Cucurbitaria) of the family clustered in a clade comprises six strains of Cucurbitaria berberidis i.e. ex-epitype strain (MFLUCC 11-0384), iso-epitype strains (MFLUCC 11-0384, MFLUCC 11-0385, MFLUCC 11-0386, MFLUCC 11-0387), representative strains (CBS 363.93, CBS 394.84) and C. ephedricola (HA 42). It is interesting to note that all Cucurbitaria berberidis isolates and $C$. ephedricola cluster together and could not be segregated based on our phylogenetic analyses. In the Cucurbitaria group only $28 \mathrm{~S}$ and $18 \mathrm{~S}$ rDNA sequence data are used (which are rather too conserved for species delineation) and hence the strains are phylogenetically indistinguishable. However, they are morphologically different (Ariyawansa et al. 2015). Only Cucurbitaria berberidis (CBS 394.84) has ITS sequence data available and it would be wise to consider or evaluate the utility of several other protein genes such as DNA-directed ribosomal polymerase II (RPB2) or translation elongation factor alpha 1 (tef1- $\alpha$ ) to further elucidate phylogenetic relationships among this group of fungi with fresh collections.

Three strains of Pyrenochaeta corni (CBS 234.92, CBS 248.79, CBS 102828) grouped in a clade with 86\% ML / 82\% MP / 1.00 BYPP statistical support (clade E, Fig. 1). Pyrenochaeta nobilis isolates (CBS 292.74, CBS 407.76, CBS 566.75) grouped together with strong support (89\% ML / 82\% MP / 0.98 BYPP, Fig. 1), but surprisingly its affinity with other Pyrenochaeta species within clade F (characterised as the Pyrenochaeta sensu stricto clade) is unresolved (no support). A similar phylogenetic scenario is observed with $P$. corni characterized as the Pyrenochaeta sensu lato clade. Apart from the Pyrenochaeta nobilis group, clade F comprised a few subclades with significant statistical support i.e. Pyrenochaeta acicola (CBS 812.95, CBS 101634, CBS 124142, ICMP 6610, MUT 4382) with 99\% ML \& MP support and Pyrenochaeta telephoni (CBS 139022) with 98\% ML / 92\% MP / 1.00 BYPP support and two strains of Pyrenochaeta lycopersici (CBS 267.59, CBS 306.65) with 100\% ML and 99\% MP / 1.00 BYPP statistical support. 
The Pyrenochaetopsis species are well-supported in all analyses with good statistical support i.e. 99\% ML / 96\% MP / 1.00 BYPP (Fig. 1, clade G). Clade G comprises Pyrenochaetopsis decipiens (CBS 165.89, CBS 343.85), P. indica (CBS 124454), P. leptospora (CBS 131.69, CBS 536.66, CBS 101635), P. microspora (CBS 101333, CBS 102876, CBS 119739), P. pratorum (CBS 286.93, CBS 445.81) and P.poae (CBS 136769).

\section{Taxonomy}

Cucurbitariaceae G. Winter, Rabenhorst's Kryptogamen-Flora, Pilze - Ascomyceten 1(2): 308 (1885)

= Fenestellaceae M.E. Barr, Mycologia 71(5): 952 (1979)

Type - Cucurbitaria Gray, A natural arrangement of British plants 1: 519 (1821)

Type species - Cucurbitaria berberidis (Pers.) Gray, A natural arrangement of British plants 1: $519(1821)$

Fenestella Tul. \& C. Tul., Selecta Fungorum Carpologia: Xylariei- Valsei- Spaeriei 2: 207 (1863)

Type species - Fenestella princeps Tul. \& C. Tul., Selecta Fungorum Carpologia: XylarieiValsei- Spaeriei 2: 207 (1863)

Notes - Fenestella was introduced by Tulasne \& Tulasne (1863) and is typified by $F$. princeps. The genus was introduced to accommodate Dothideomycetes species forming valsoid ascostromata and brown to reddish-brown, muriform ascospores (Barr 1979, Hyde et al. 2013, Phookamsak \& Hyde 2015). Fenestella is relatively poorly studied and the type species of the genus could not be located. Therefore, Phookamsak \& Hyde (2015) revisited the family Fenestellaceae and transferred the genus Lojkania Rehm to Testudinaceae, maintaining Fenestella in Fenestellaceae.

Fenestella can be distinguished from other genera in Cucurbitariaceae by its arrangement of locules in the ascostromata and the peridium structure (Doilom et al. 2013, Phookamsak \& Hyde 2015). Although, these characters can distinguish Fenestella from other genera in Cucurbitariaceae, they are inappropriate for generic delineation (Phookamsak \& Hyde 2015). it is not significant to separate them at the family level (Phookamsak \& Hyde 2015). However, Phookamsak \& Hyde (2015) maintained the monotypic genus Fenestella in Fenestellaceae due to the lack of a modern taxonomic description of the genus and limited molecular data. In this study, two new taxa are introduced which are morphologically typical of Fenestella viz. $F$. ostryae sp. nov. and $F$. mackenziei sp. nov. Phylogenetically, F. ostryae and F. mackenziei cluster together with good support and share a close phylogenetic affinity to $F$. fenestrata (CBS 114122) within the family Cucurbitariaceae. With this updated phylogeny where Fenestellaceae is nested in between Cucurbitariaceae and insufficient morphological grounds to support Fenestellaceae as an independent family, we propose Fenestella to be transferred to Cucurbitariaceae and Fenestellaceae be synonymized with Cucurbitariaceae.

The asexual morph of Fenestella has been reported as the coelomycetous genus Pleurostromella having oblong, hyaline, aseptate conidia (Brefeld 1891, Huhndorf \& Glawe 1990, Wijayawardene et al. 2012, Hyde et al. 2013, Phookamsak \& Hyde 2015). However, the generic type of Pleurostromella, $P$. ulmicola lacks molecular data to confirm its phylogenetic affinity and the link between sexual and asexual morphs (Fenestella and Pleurostromella) has not yet been clarified. In this study, the asexual morph of $F$. ostryae was recovered from culture (PDA), confirming the coelomycetous asexual status of Fenestella. The asexual morph of Fenestella resembles the genus Pyrenochaeta, but they are phylogenetically distinct.

Fenestella ostryae Wanas., Camporesi, E.B.G. Jones \& K.D. Hyde, sp. nov.

Figs 2-3

Index Fungorum Number - IF552830

Facesoffungi Number - FoF 02900

Etymology - Name reflects the host genus Ostrya.

Holotype - MFLU 16-0184 


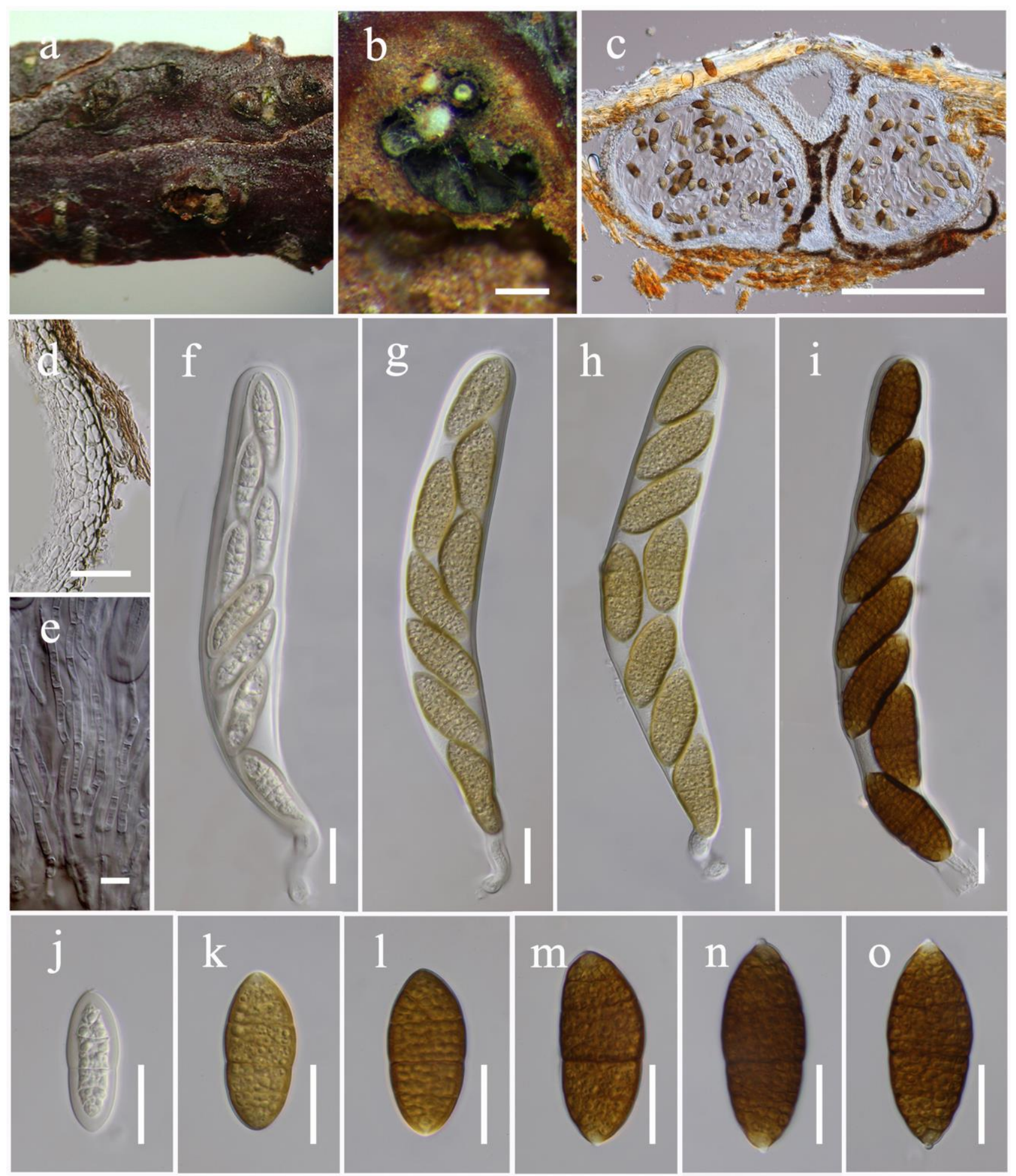

Fig. 2 - Fenestella ostryae (MFLU 16-0184, holotype). a Appearance of ascostromata on host substrate. b Horizontal section through ascostromata illustrating the multilocules at the upper layers. c Vertical section through ascostroma. d Peridium. e Pseudoparaphyses. f-i Asci. j-o Ascospores. Scale bars: $\mathrm{b}, \mathrm{c}=200 \mu \mathrm{m}, \mathrm{d}, \mathrm{f}-\mathrm{O}=20 \mu \mathrm{m}, \mathrm{e}=5 \mu \mathrm{m}$.

Saprobic on dead twigs of Ostrya carpinifolia Scop. Sexual morph: Ascostromata 300-550 $\mu \mathrm{m}$ high, $450-800 \mu \mathrm{m}$ diam. $(\bar{x}=431.6 \times 620.4 \mu \mathrm{m}, \mathrm{n}=5)$, solitary, immersed to erumpent through host periderm, visible as raised, circular areas with a central sunken area, with blackened ostiolar dots, with 1-5 locules in a valsoid configuration. Locules $250-450 \mu \mathrm{m}$ high, $350-500 \mu \mathrm{m}$ diam. $(\bar{x}$ $=351.6 \times 400.1 \mu \mathrm{m}, \mathrm{n}=5$ ), clustered or gregarious, immersed in valsoid groups beneath periderm of host, multi-loculate, ovoid to obpyriform, glabrous, covered by vegetative hyphae, dark brown to black. Peridium 35-60 $\mu \mathrm{m}$ wide at the base, 20-40 $\mu \mathrm{m}$ wide at the sides, comprising 4-6 

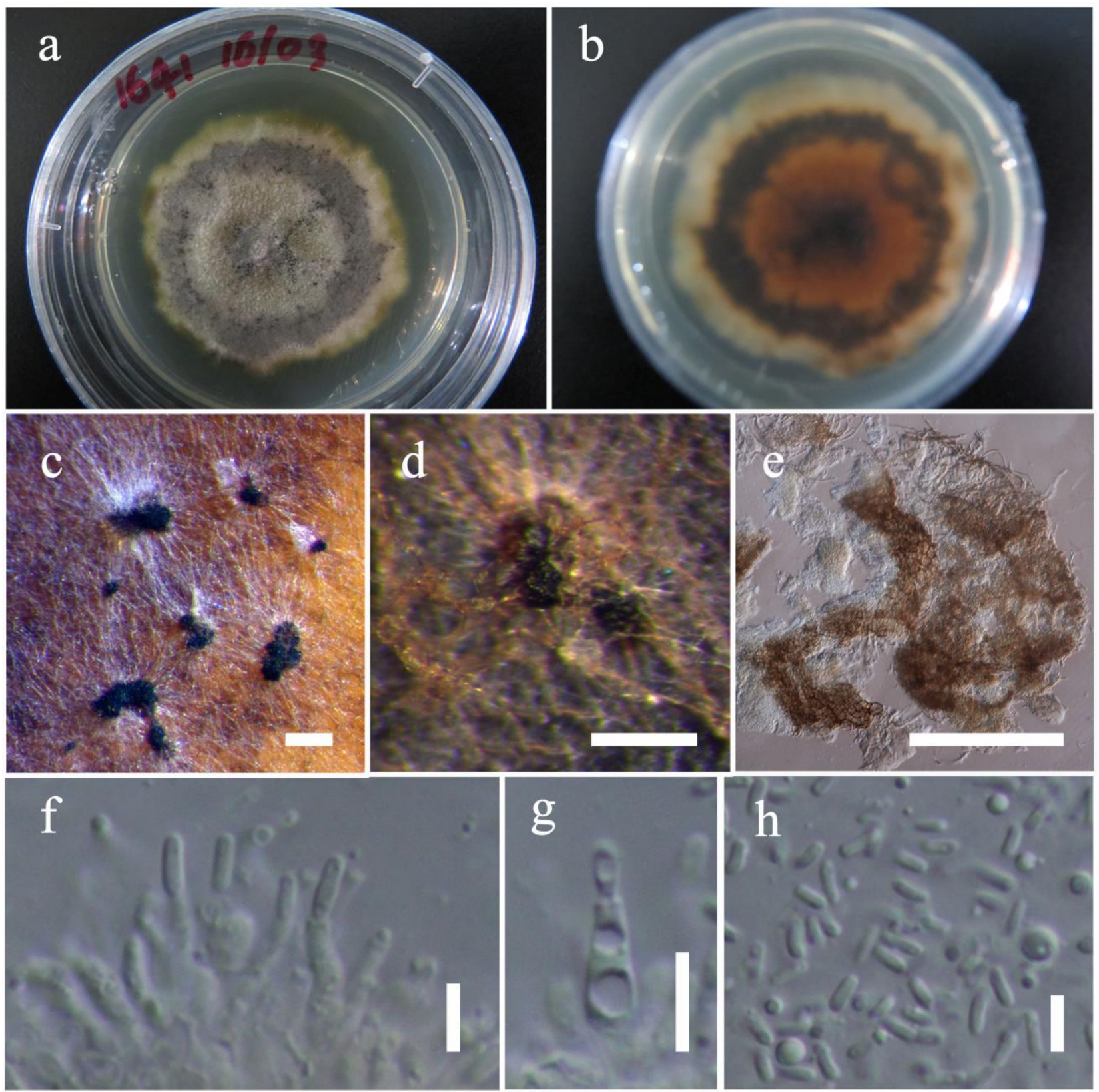

Fig. 3 - Asexual morph of Fenestella ostryae forming on PDA after 8 weeks (MFLU 16-0184, holotype) $\mathbf{a}, \mathbf{b}$ Culture on PDA ( $\mathrm{a}=$ from above, $\mathrm{b}=$ from below). $\mathbf{c}, \mathbf{d}$ Conidiomata on colony. $\mathbf{e}$ Squashed conidiomata. f, $\mathbf{g}$ Mature and immature conidia attached to conidiogenous cells. $\mathbf{h}$ Mature and immature conidia. Scale bars: $\mathrm{c}-\mathrm{e}=200 \mu \mathrm{m}, \mathrm{f}-\mathrm{h}=5 \mu \mathrm{m}$.

layers, outer layer pigmented, comprising reddish-brown to dark brown, thin-walled cells of textura angularis, inner layer composed of hyaline, flattened, thin-walled cells of textura angularis. Hamathecium comprising numerous, 2-3.5 $\mu \mathrm{m}$ wide, filamentous, branched, septate, pseudoparaphyses. Asci 190-210 × 20-30 $\mu \mathrm{m}(\bar{x}=202.2 \times 24.9 \mu \mathrm{m}, \mathrm{n}=30), 8$-spored, bitunicate, fissitunicate, cylindrical to cylindric-clavate, with a $10-40 \mu \mathrm{m}$ long pedicel, apically rounded, with a minute ocular chamber. Ascospores 40-50 $\times 15-20 \mu \mathrm{m}(\bar{x}=45.6 \times 18.1 \mu \mathrm{m}, \mathrm{n}=40)$, overlapping uni-seriate, muriform, ellipsoidal to broadly fusiform, hyaline to pale brown when young, becoming dark brown at maturity, paler at the extreme ends, with 6-12 transverse septa and 3-4 longitudinal septa, slightly constricted at the central septum, upper part larger than the lower part, guttulate in each cell, ends remaining cone-shaped, with pointed ends. Asexual morph: Coelomycetous, phoma-like. Pycnidia solitary to confluent, on upper surface or submerged in agar, globose to subglobose, ostiole apapillate or papillate, olivaceous to olivaceous-black, the wall with pseudoparenchymatous cells. Conidiophores hyaline, cylindrical, arising from the inner wall of the 
conidioma. Conidiogenous cells 5-7 $\times 2-4 \mu \mathrm{m}(\bar{x}=6.6 \times 2.9 \mu \mathrm{m}, \mathrm{n}=20)$, hyaline, enteroblastic, phialidic, doliiform to cylindrical, straight or slightly curved, indeterminate, discrete, or integrated, septate. Conidia 2.8-4 $\times 1-1.5 \mu \mathrm{m}(\bar{x}=3.4 \times 1.2 \mu \mathrm{m}, \mathrm{n}=30)$, hyaline, aseptate, cylindrical/ellipsoidal to allantoid, not often guttulate, smooth-walled.

Culture characteristics - Colonies on PDA reaching $2 \mathrm{~cm}$ diam. after 30 days at $16 \mathrm{C}$, circular, margin white at first, dark grey outer and creamy center after 4 weeks, flat on the surface, without aerial mycelium, reverse iron to greenish grey. Hyphae septate branched, hyaline, thin, smooth-walled.

Known distribution - Italy, on dead twigs of Ostrya carpinifolia (Betulaceae).

Material examined - Italy, Forlì-Cesena, Galeata, Strada San Zeno, on dead aerial twigs of Ostrya carpinifolia, 11 January 2014, Erio Camporesi, IT 1641 (MFLU 16-0184, holotype) isotype in BBH, ex-type living culture, MFLUCC 17-0097.

Notes - Fenestella ostryae closely resembles F. fenestrata in having immersed, multiloculate ascostromata, cylindrical to cylindric-clavate asci and ellipsoidal to broadly fusiform ascospores, which are paler at the extreme ends. Their phylogenetic relationship remains uncertain due to the unavailability of molecular data from the type material of $F$. fenestrata. However, $F$. fenestrata has comparatively larger ascostromata and longer asci than $F$. ostryae (see Table 2).

In this study, Fenestella mackenziei groups as a sister taxon to $F$. ostryae which was also collected from Forlì-Cesena Province in Italy. They are morphologically similar in ascal and ascospores characteristics, i.e. shape and septation, but morphometric dimensions are considerably different (see Table 2). In addition, Fenestella ostryae has multi-loculate ascostromata and $F$. mackenziei has uni-loculate ascomata. ITS sequence comparison also reveals 19 base pair differences between the two taxa and hence we introduce them as two new species which is in concordance to Jeewon \& Hyde (2016).

Fenestella mackenziei Wanas., Camporesi, E.B.G. Jones \& K.D. Hyde, sp. nov.

Fig. 4

Index Fungorum Number - IF552831

Facesoffungi Number - FoF 02901

Etymology - In honour of Dr. Eric Hugh Charles McKenzie for his immense contribution to mycology

Holotype - MFLU 16-0181

Saprobic on dead twigs of Rosa canina L. Sexual morph: Ascomata 250-350 $\mu \mathrm{m}$ high, 300-450 $\mu \mathrm{m}$ diam. $(\bar{x}=337.8 \times 364.8 \mu \mathrm{m}, \mathrm{n}=5)$, solitary or scattered, immersed to semierumpent through host tissues, visible as raised, circular areas with a central sunken area, with blackened ostiolar dots, globose to subglobose in shape, glabrous, dark brown to black, ostiolate. Ostiole 60-90 $\mu \mathrm{m}$ high, 50-70 $\mu \mathrm{m}$ diam. $(\bar{x}=78.2 \times 58.9 \mu \mathrm{m}, \mathrm{n}=5)$, black, smooth, with ostiolar canal filled with hyaline cells. Peridium $20-30 \mu \mathrm{m}$ wide at the base, 30-60 $\mu \mathrm{m}$ wide at the sides, comprising 4-6 layers, outer layer pigmented, comprising reddish-brown to dark brown, thickwalled cells of textura angularis, inner layer composed of hyaline, flattened, thin-walled cells of textura angularis. Hamathecium comprising numerous, $2-2.5 \mu \mathrm{m}$ wide, filamentous, branched, septate, pseudoparaphyses. Asci 140-200 × 20-25 $\mu \mathrm{m}(\bar{x}=168.2 \times 22.6 \mu \mathrm{m}, \mathrm{n}=30)$, 8-spored, bitunicate, fissitunicate, cylindrical to cylindric-clavate, with a 10-20 $\mu \mathrm{m}$ long pedicel, apically rounded, with a minute ocular chamber. Ascospores $25-32 \times 11-15 \mu \mathrm{m}(\bar{x}=30.1 \times 13.1 \mu \mathrm{m}, \mathrm{n}=$ 40 ), overlapping uni-seriate, muriform, ellipsoidal to broadly fusiform, hyaline to pale brown when young, becoming dark brown at maturity, paler at the extreme ends, with 6-10 transverse septa and 2-4 longitudinal septa, slightly constricted at the central septum, upper part larger than the lower part, guttulate in each cell, ends remaining cone-shaped, with pointed ends. Asexual morph: Undetermined.

Culture characteristics - Colonies on PDA reaching $2 \mathrm{~cm}$ diam. after 30 days at $16^{\circ} \mathrm{C}$, circular, margin white at first, dark grey outer and creamy center after 4 weeks, flat on the surface, without aerial mycelium, reverse iron to greenish-grey. Hyphae septate branched, hyaline, thin, smoothwalled. 

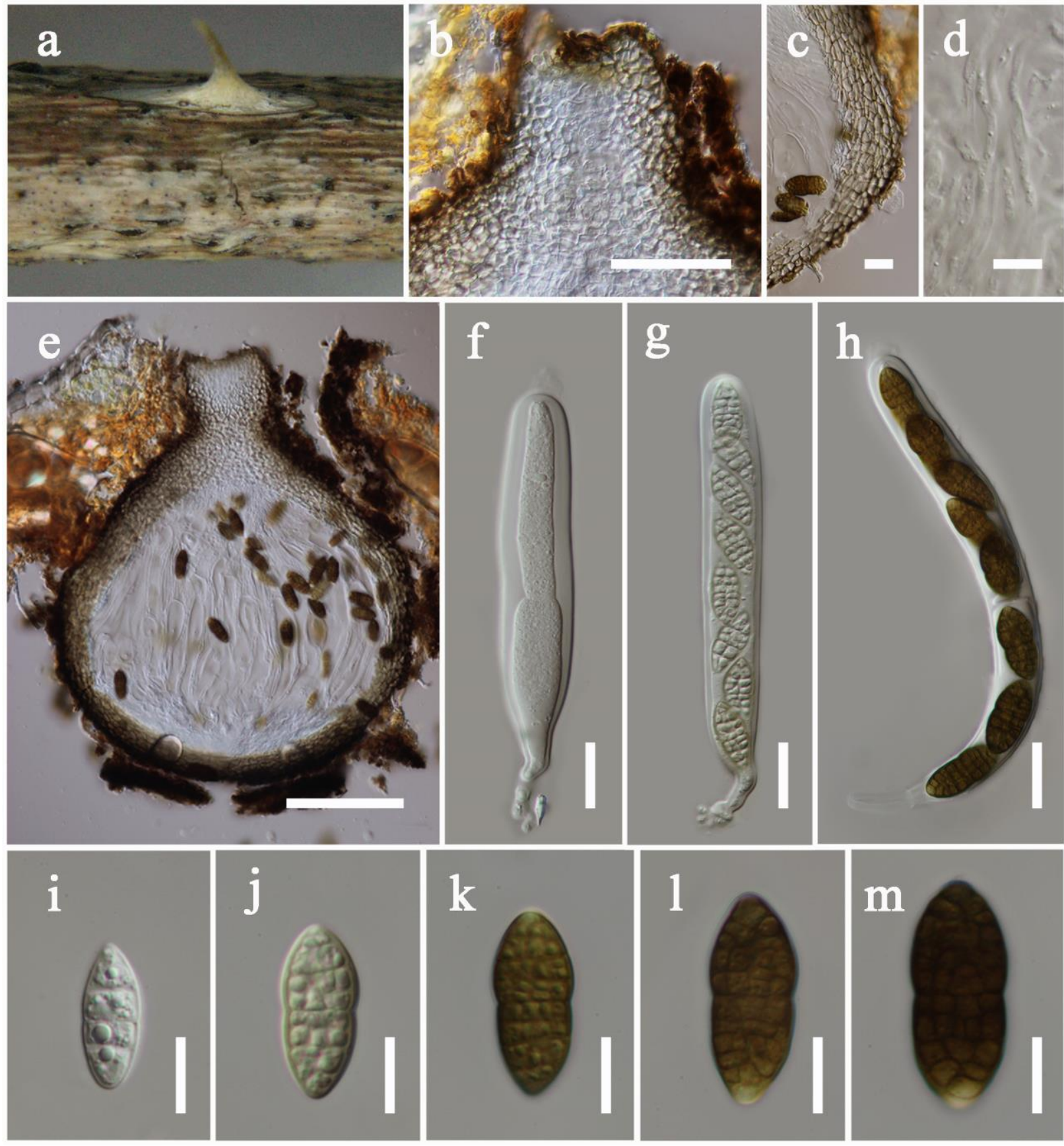

Fig. 4 - Fenestella mackenziei (MFLU 16-0181, holotype). a Appearance of ascomata on host substrate. b Section of ascoma. c Peridium. d Pseudoparaphyses. e-h Asci. i-n Ascospores. Scale bars: $b=100 \mu \mathrm{m}, \mathrm{c}, \mathrm{e}-\mathrm{n}=20 \mu \mathrm{m}, \mathrm{d}=5 \mu \mathrm{m}$.

Known distribution - Italy, on dead twigs of Rosa canina (Rosaceae).

Material examined - Italy, Forlì-Cesena, San Benedetto in Alps, dead aerial twigs of Rosa canina, 26 December 2013, Erio Camporesi, IT 1601 (MFLU 16-0181, holotype) isotype in BBH, ex-type living culture, MFLUCC 16-1451.

Notes - See above notes under Fenestella ostryae.

Neocucurbitaria Wanas., E.B.G. Jones \& K.D. Hyde, gen. nov.

Index Fungorum Number - IF552832

Facesoffungi Number -02902

Etymology - Name reflects the fact that although morphologically similar, it is distinct from the genus Cucurbitaria 
Table 2. Synopsis of Fenestella species with morphological features discussed in this study.

\begin{tabular}{|c|c|c|c|c|c|c|}
\hline \multirow[b]{2}{*}{ Species } & \multirow{2}{*}{$\begin{array}{l}\text { Ascomata/ } \\
\text { Ascostromata } \\
(\mu \mathrm{m})\end{array}$} & \multirow{2}{*}{$\begin{array}{l}\text { Number } \\
\text { of locules }\end{array}$} & \multirow[b]{2}{*}{$\operatorname{Asci}(\mu \mathrm{m})$} & \multicolumn{3}{|c|}{ Ascospores } \\
\hline & & & & Size $(\mu \mathrm{m})$ & $\begin{array}{l}\text { Transvers } \\
\text { e septa }\end{array}$ & $\begin{array}{l}\text { Longitudin } \\
\text { al septa }\end{array}$ \\
\hline $\begin{array}{l}\text { Fenestella } \\
\text { fenestrata }^{1}\end{array}$ & $\begin{array}{c}\text { 550-680 high } \\
850-1530 \text { diam. }\end{array}$ & $2-5$ & $\begin{array}{c}176-330 \times 24.5- \\
32\end{array}$ & $\begin{array}{c}39-53 \times 15- \\
20\end{array}$ & $7-8$ & $3-4$ \\
\hline $\begin{array}{l}\text { Fenestella } \\
\text { mackenziei }{ }^{2}\end{array}$ & $\begin{array}{l}\text { 250-350 high } \\
300-450 \text { diam. }\end{array}$ & 1 & $\begin{array}{l}140-200 \times 20-25 \\
\text { stipe } 10-20 \text { long }\end{array}$ & $\begin{array}{c}25-32 \times 11- \\
15\end{array}$ & $6-10$ & $2-4$ \\
\hline $\begin{array}{l}\text { Fenestella } \\
\text { ostryae }^{2}\end{array}$ & $\begin{array}{l}\text { 300-550 high } \\
450-800 \text { diam. }\end{array}$ & $1-5$ & $\begin{array}{l}190-210 \times 20-30 \\
\text { stipe } 10-40 \text { long }\end{array}$ & $\begin{array}{c}40-50 \times 15- \\
20\end{array}$ & $6-12$ & $3-4$ \\
\hline $\begin{array}{l}\text { Fenestella } \\
\text { princeps }^{1}\end{array}$ & & $\begin{array}{l}\text { Multi- } \\
\text { loculate }\end{array}$ & $\begin{array}{c}300-440 \times 23-28 \\
\text { stipe } 30-90 \text { long }\end{array}$ & $\begin{array}{c}50-62 \times 16- \\
23\end{array}$ & $3-6$ & $3-4$ \\
\hline
\end{tabular}

${ }^{1}$ Phookamsak \& Hyde (2015), ${ }^{2}$ This study

Saprobic on dicotyledons, trees and shrubs in terrestrial habitat or parasitic on human skin. Sexual morph: Ascomata black, superficial to semi-immersed, confluent, gregarious, sometimes scattered beneath the host periderm or on decorticated wood, fully or partly erumpent, globose, uniloculate, with an ostiole. Ostiole central, slightly sunken, short and broad papillate, inconspicuous at the surface, black, smooth, filled with hyaline periphyses. Peridium comprising 610 layers, outer most layer heavily pigmented, thin-walled, comprising blackish to dark brown amorphous layer, middle layer heavily pigmented, thick-walled, comprising blackish to dark brown loosely packed cells of textura angularis, inner layer composed 3-4 layers, reddish-brown to hyaline, cells towards the inside comprising lighter, flattened, thick-walled cells of textura angularis. Hamathecium comprising numerous, filamentous, branched, septate pseudoparaphyses. Asci 8-spored, bitunicate, fissitunicate, cylindrical, short-pedicellate, apex rounded with a minute ocular chamber. Ascospores overlapping uniseriate, muriform, mostly ellipsoidal, 6-8 transverse septa, with a longitudinal septum, deeply constricted at the middle septum, slightly constricted at remaining septa, initially hyaline, becoming pale brown at maturity, symmetrical, slightly paler ends, conical and narrowly rounded at the ends. Asexual morph: Coelomycetous. Conidiomata pycnidial, solitary to confluent, globose to subglobose, papillate ostiolate. Ostiole single, central, circular. Setae abundant around the ostiole, erect, dark brown to black, thick-walled. Conidiogenous cell doliiform to cylindrical, septate, hyaline. Conidia hyaline, aseptate, cylindrical/ellipsoidal, smooth-walled (Sutton 1980).

Type species - Neocucurbitaria unguis-hominis (Punith. \& M.P. English) Wanas., E.B.G. Jones \& K.D. Hyde

Notes - De Notaris (1849) introduced Pyrenochaeta to accommodate $P$. nobilis as the type species and twelve other closely related taxa, which are characterized by branched, filiform, septate, acropleurogenous conidiophores (Schneider 1979, de Gruyter et al. 2010). A number of Pyrenochaeta species e.g. P. cava, P. corni and P. quercina are important either as endophytes, saprobes or pathogens such as $P$. lycopersici in agriculture and forestry (de Gruyter et al. 2010, Clergeot et al. 2012). Furthermore, they can be human pathogens that cause infection of human skin and nails e.g Pyrenochaeta unguis-hominis (Toh et al. 2016).

The taxonomy of Pyrenochaeta species has been studied by de Gruyter et al. (2010), but their pleomorphism has received little attention, and thus, the basic biology of this group is not fully understood. De Gruyter et al. (2010) accepted Cucurbitaria as the sexual morph of Pyrenochaeta. However, in this study Pyrenochaeta nobilis, the type species of Pyrenochaeta, is phylogenetically distant from Cucurbitaria berberidis, the type species of Cucurbitaria, and this was accepted in Doilom et al. (2013). Our phylogeny also indicates that the affinities of $P$. nobilis are uncertain as its isolates constitute an independent lineage distinct from other species. The taxonomy of this species needs revision with more fresh collections as there are only slight morphologically differences with other species. 
In this study, Pyrenochaeta quercina (CBS 297.74, CBS 115095) and P. unguis-hominis (CBS 112.79, CBS 378.92, CBS 111112) cluster as sister groups in a well-supported clade (78\% ML and 0.96 BYPP, clade C, Fig. 1), with one of our newly isolated sexual morphs. This new isolate (Neocucurbitaria acerina) is shown to be the sexual morph of pyrenochaeta-like species and differs from other sexual morphs recorded in Cucurbitariaceae (see the notes under Neocucurbitaria acerina). Pyrenochaeta quercina strains are not from the type material and it is difficult to infer an accurate relationship between $P$. quercina and our new sexual isolate. Pyrenochaeta unguis-hominis also differs from the type species, P. nobilis, in conidiogenesis. Pyrenochaeta unguis-hominis has phoma-like conidiogenous cells, whereas $P$. nobilis has acropleurogenous conidiogenesis. In addition, Pyrenochaeta unguis-hominis has comparatively smaller conidia (3-3.5 $\mu \mathrm{m} \times 1-1.5 \mu \mathrm{m}$.) than P. nobilis $(4.8-7.5 \mu \mathrm{m} \times 1-1.5 \mu \mathrm{m})$. Based on DNA sequence data coupled with morphological evidence we introduce Neocucurbitaria to accommodate Neocucurbitaria acerina, Pyrenochaeta quercina and P. unguis-hominis.

Neocucurbitaria acerina Wanas., Camporesi, E.B.G. Jones \& K.D. Hyde sp. nov.

Fig. 5

Index Fungorum Number - IF552833

Facesoffungi Number - FoF 02903

Etymology - Name reflects the host genus Acer.

Holotype - MFLU 16-2710

Endophytic or saprobic on Acer campestre, trees and shrubs in terrestrial habitat. Sexual morph: Ascomata 250-350 $\mu \mathrm{m}$ high 300-450 $\mu \mathrm{m}$ diam. $(\bar{x}=329.6 \times 399.7 \mu \mathrm{m}, \mathrm{n}=10)$, black, superficial to semi-immersed, confluent, gregarious, sometimes scattered beneath the host periderm or on decorticated wood, fully or partly erumpent, globose, uniloculate, with an ostiole. Ostiole 50 $70 \mu \mathrm{m}$ long 70-100 $\mu \mathrm{m}$ diam., centrally located, slightly sunken, short and broad papillate, inconspicuous at the surface, black, smooth, filled with hyaline periphyses. Peridium 25-30 $\mu \mathrm{m}$ wide at the base, 50-70 $\mu \mathrm{m}$ wide in sides, thick, comprising 6-10 layers, outer most layer heavily pigmented, thin-walled, comprising blackish to dark brown amorphous layer, middle layer heavily pigmented, thick-walled, comprising blackish to dark brown loosely packed cells of textura angularis, inner layer composed 3-4 layers, reddish brown to hyaline, cells towards the inside lighter, flattened, thick-walled cells of textura angularis. Hamathecium comprising numerous, 2$2.5 \mu \mathrm{m}(\mathrm{n}=40)$ wide, filamentous, branched septate, pseudoparaphyses. Asci 100-110 $\times 10-12 \mu \mathrm{m}$ $(\bar{x}=105.8 \times 10.6 \mu \mathrm{m}, \mathrm{n}=40), 8$-spored, bitunicate, fissitunicate, cylindrical, short-pedicellate, apex rounded with a minute ocular chamber. Ascospores 15-20 $\times 6-9 \mu \mathrm{m}(\bar{x}=19.4 \times 7.1 \mu \mathrm{m}, \mathrm{n}=$ 50), overlapping uniseriate, muriform, mostly ellipsoidal, 6-8 transverse septa, with a longitudinal septum, deeply constricted at the middle septum, slightly constricted at remaining septa, initially hyaline, becoming pale brown at maturity, symmetrical, slightly paler ends, conical and narrowly rounded at the ends. Asexual morph: Undetermined.

Culture characteristics - Colonies on PDA reaching $3 \mathrm{~cm}$ diam. after 30 days at $16{ }^{\circ} \mathrm{C}$, circular, smooth margin white at first, dark lava after 4 weeks flat on the surface, without aerial mycelium, reverse grayish black. Hyphae septate branched, hyaline, thin, smooth-walled.

Known distribution - Italy, on dead twigs of Acer campestre L. (Sapindaceae)

Material examined - Italy, Forlì-Cesena, Fiumicello di Premilcuore, on dead aerial twigs of Acer campestre, 20 November 2013, Erio Camporesi, IT1527 (MFLU 16-2710, holotype), isotype in BBH, living culture, MFLUCC 16-1450.

Notes - In this study, we introduce a novel taxon as a possible sexual morph of Pyrenochaeta quercina from Italy on Acer campestre based on a combined gene analyses of ITS, LSU and SSU sequence data. Our new species resembles Cucurbitaria in having semi-immersed, globose ascomata with a central ostiole, short-pedicellate asci with a minute ocular chamber and overlapping uniseriate, pale brown, muriform ascospores. However, there are differences as Neocucurbitaria acerina has mostly solitary ascomata, ostiole with hyaline periphyses, smaller asci $(<110 \times 12 \mu \mathrm{m})$ and smaller ascospores $(<20 \times 9 \mu \mathrm{m})$ with 1-longitudinal septum, while 

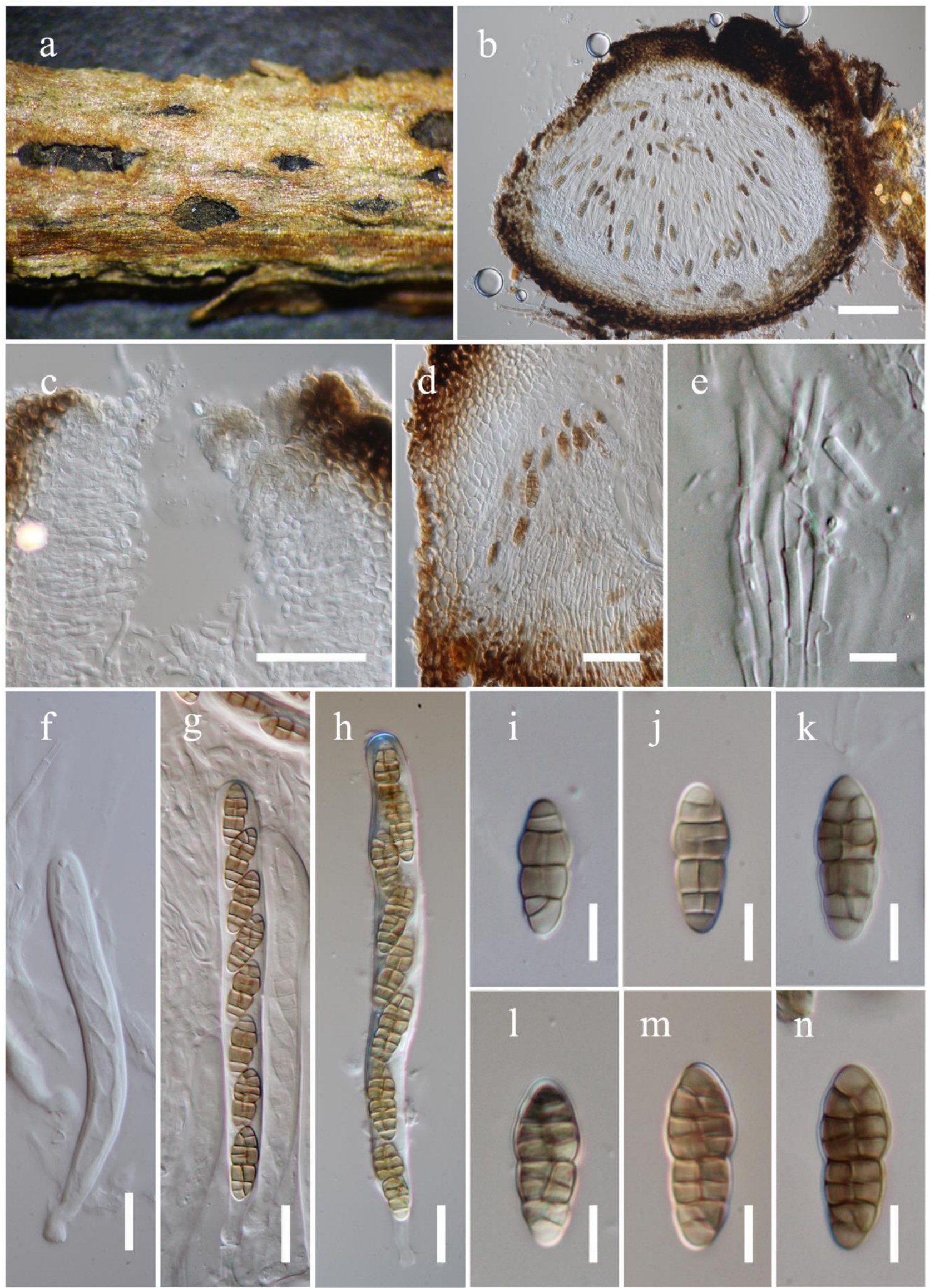

Fig. 5 - Neocucurbitaria acerina (MFLU 16-2710, holotype). a. Appearance of ascomata on host substrate. b. Vertical section of ascoma. c. Close up of ostiole. d. Peridium. e. Pseudoparaphyses. fh. Asci. i-n. Ascospores. Scale bars: $\mathrm{b}=100 \mu \mathrm{m}, \mathrm{c}, \mathrm{d}=50 \mu \mathrm{m}, \mathrm{e}, \mathrm{i}-\mathrm{n}=10 \mu \mathrm{m}, \mathrm{f}-\mathrm{h}=20 \mu \mathrm{m}$. 
Cucurbitaria species have gregarious ascomata, ostiole without periphyses, larger asci $(>150 \times 12$ $\mu \mathrm{m})$ and larger ascospores $(>20 \times 9 \mu \mathrm{m})$ with more than a 1-longitudinal septum (Table 3 ).

Neocucurbitaria quercina (Kabát \& Bubák) Wanas., E.B.G. Jones \& K.D. Hyde, comb. nov. Index Fungorum Number - IF552834

Facesoffungi Number - FoF 02904

Basionym - Pyrenochaeta quercina Kabát \& Bubák, Hedwigia 52: 342 (1912)

Notes - See above notes under Neocucurbitaria.

Neocucurbitaria unguis-hominis (Punith. \& M.P. English) Wanas., E.B.G. Jones \& K.D. Hyde comb. nov.

Index Fungorum Number - IF552835

Facesoffungi Number - FoF 02905

Basionym - Pyrenochaeta unguis-hominis Punith. \& M.P. English, Trans. Br. mycol. Soc. 64(3): 539 (1975)

Notes - See above notes under Neocucurbitaria.

Table 3. Synopsis of Cucurbitaria berberidis, C. ephedricola and Neocucurbitaria acerina species with morphological features discussed in this study.

\begin{tabular}{|c|c|c|c|}
\hline Species & Ascomata $(\mu \mathrm{m})$ & Periphyses & Ascospore $(\mu \mathrm{m})$ \\
\hline & Less commonly solitary & & $23-32 \times 9-14$ \\
\hline Cucurbitaria berberidis ${ }^{1}$ & $\begin{array}{l}\text { 400-900 high } \\
400-600 \text { diam. }\end{array}$ & Absent & $\begin{array}{r}180-200 \times 20-307-9 \text {-transverse septa } \\
3-4-\text { longitudinal septa }\end{array}$ \\
\hline Cucurbitaria ephedricola ${ }^{2}$ & $\begin{array}{l}\text { Less commonly solitary } \\
\text { 300-800 diam. }\end{array}$ & Absent & $\begin{array}{c}20-30 \times 10-15 \\
150-200 \times 13-205-9 \text {-transverse septa } \\
1-2 \text {-longitudinal septa }\end{array}$ \\
\hline Neocucurbitaria acerina ${ }^{3}$ & $\begin{array}{l}\text { Commonly solitary } \\
250-350 \text { high } \\
300-450 \text { diam. }\end{array}$ & Hyaline & $\begin{array}{c}15-20 \times 6-9 \\
100-110 \times 10-126-8 \text {-transverse septa } \\
1 \text {-longitudinal septum }\end{array}$ \\
\hline
\end{tabular}

${ }^{1}$ Doilom et al. (2013), ${ }^{2}$ Ariyawansa et al. (2015), ${ }^{3}$ This study

\section{Acknowledgments}

Dhanushka Wanasinghe thanks to Hiran Ariyawansa, Saowaluck Tibpromma, Danushka Tennakoon for their valuable suggestions and help. Rungtiwa Phookamsak thanks to CGIAR Research Program 6: Forest, Trees and Agroforestry for partially financial support. R Jeewon is grateful to Mae Fah Luang University for inviting him as a visiting professor and a keynote speaker for the COEIC 2017 conference.

\section{References}

Ariyawansa HA, Hyde KD, Jayasiri SC, Buyck B et al. 2015 - Fungal diversity notes 111-252taxonomic and phylogenetic contributions to fungal taxa. Fungal Diversity 75, 27-274.

Barr ME. 1979 - A classification of Loculoascomycetes. Mycologia 71, 935-957.

Barr ME. 1987 - Prodomus to class Loculoascomycetes. Published by the author, Amherst, Massachusetts. p 90.

Brefeld O. 1891 - Unter suchungen aus dem gesammtge biete der Mycologie. 10. Ascomyceten. II. Münster. p 378.

Chomnunti P, Hongsanan S, Hudson BA, Tian Q et al. 2014 - The sooty moulds. Fungal Diversity $66,1-36$.

Clergeot PH, Rivetti C, Hamiduzzaman MM, Ekengren S. 2012 - The corky root rot pathogen Pyrenochaeta lycopersici manipulates tomato roots with molecules secreted early during their interaction. Acta Agriculturae Scandinavica - Section B. 62, 300-310. 
Crous PW, Wingfield MJ, Le Roux JJ, Richardson et al. 2015 - Fungal Planet Description Sheets: 371-399. Persoonia 35, 264-327.

de Gruyter J, Woudenberg JH, Aveskamp MM, Verkley GJ et al. 2010 - Systematic reappraisal of species in Phoma section Paraphoma, Pyrenochaeta and Pleurophoma. Mycologia 102, 1066-1081.

de Notaris. 1845 - Micromycetes Italici novi vel minus cogniti. V. Memorie della Reale Accademia delle Scienze di Torino Ser. 2. 10, 333-350.

Doilom M, Liu JK, Jaklitsch WM, Ariyawansa H et al. 2013 - An outline of the family Cucurbitariaceae. Sydowia 65, 167-192.

Hall TA. 1999 - BioEdit: a user-friendly biological sequence alignment editor and analysis program for Windows 95/98/NT. Nucleic Acids Symposium Series No. 41, 95-98.

Huelsenbeck JP, Ronquist F. 2001 - MRBAYES: Bayesian inference of phylogenetic trees. Bioinformatics 17, 754-755.

Huhndorf SM, Glawe DA. 1990 - Pycnidial development from ascospores of Fenestella princeps. Mycologia 82, 541-548.

Hyde KD, Jones EBG, Liu JK, Ariyawansa HA et al. 2013 - Families of Dothideomycetes. Fungal Diversity 63, 1-313.

Jayasiri SC, Hyde KD, Ariyawansa HA, Bhat J et al. 2015 - The Faces of Fungi database: fungal names linked with morphology, phylogeny and human impacts. Fungal Diversity 74, 3-18.

Jeewon R, Hyde KD. 2016 - Establishing species boundaries and new taxa among fungi: recommendations to resolve taxonomic ambiguities. Mycosphere 7, 1669-1677.

Jeewon R, Ittoo J, Mahadeb D, Jaufeerally-Fakim Y, Wang HK, Liu AR. 2013 - DNA based identification and phylogenetic characterisation of endophytic and saprobic Fungi from Antidesma madagascariense, a medicinal plant in mauritius. Journal of Mycology 2013, 110.

Jeewon R, Liew EC, Hyde KD. 2002 - Phylogenetic relationships of Pestalotiopsis and allied genera inferred from ribosomal DNA sequences and morphological characters. Molecular Phylogenetics and Evolution 25, 378-392.

Jeewon R, Liew EC, Simpson JA, Hodgkiss IJ et al. 2003 - Phylogenetic significance of morphological characters in the taxonomy of Pestalotiopsis species. Molecular Phylogenetics and Evolution 27, 372-383.

Jeewon R, Liew, ECY, Hyde KD. 2004 - Phylogenetic evaluation of species nomenclature of Pestalotiopsis in relation to host association. Fungal Diversity 17, 39-55.

Jeewon R, Ittoo J, Mahadeb D, Jaufeerally-Fakim Y et al. 2013 - DNA based identification and phylogenetic characterisation of endophytic and saprobic Fungi from Antidesma madagascariense, a medicinal plant in mauritius. Journal of Mycology 2013, 1-10.

Katoh K, Standley DM. 2013 - MAFFT multiple sequence alignment software version 7: improvements in performance and usability. Molecular Biology \& Evolution 30, 772-780.

Kishino H, Hasegawa M. 1989 - Evaluation of the maximum likelihood estimate of the evolutionary tree topologies from DNA sequence data, and the branching order in hominoidea. Journal of Molecular Evolution 29, 170-179.

Li GJ, Hyde KD, Zhao RL, Hongsanan S et al. 2016 - Fungal diversity notes 253-366: taxonomic and phylogenetic contributions to fungal taxa. Fungal Diversity 78, 1-237.

Miller MA, Pfeiffer W, Schwartz T. 2010 - Creating the CIPRES science gateway for inference of large phylogenetic trees. Proceedings of the Gateway Computing Environments Workshop (GCE), November 14, 2010, New Orleans, Louisiana 1-8.

Nylander JAA. 2004 - MrModeltest 2.0. Program distributed by the author. Evolutionary Biology Centre, Uppsala University.

Phookamsak R, Hyde KD. 2015 - Fenestellaceae. Mycosphere 6, 402-413.

Rambaut A, Drummond AJ. (2007 - Tracer v1, 4. Available from: http://beast.bio.ed.ac.uk/Tracer.

Rambaut, A. 2012 - FigTree version 1.4.0. Available at http://tree.bio.ed.ac.uk/software/figtree/ 
Rannala B, Yang Z. 1996 - Probability distribution of molecular evolutionary trees: a new method of phylogenetic inference. Journal of Molecular Evolution 43, 304-311.

Rehner SA, Samuels GJ. 1994 - Taxonomy and phylogeny of Gliocladium analysed from nuclear large subunit ribosomal DNA sequences. Mycological Research 98, 625-634.

Schneider R. 1979 - Die Gattung Pyrenochaeta De Notaris. Mitteilungen aus der Biologischen Bundesanstalt fur Land- und Forstwirtschaft Berlin-Dahlem 189, 1-73.

Stamatakis A. 2014 - RAxML version 8: a tool for phylogenetic analysis and post-analysis of large phylogenies. Bioinformatics 30, 1312-1313.

Stamatakis A, Hoover P, Rougemont J. 2008 - A rapid bootstrap algorithm for the RAxML web servers. Systematic Biology 57, 758-771.

Sutton BC. 1980 - The Coelomycetes. Fungi imperfecti with pycnidia, acervuli and stromata. Commonwealth Mycological Institute, Kew

Swofford DL. 2002 - PAUP: phylogenetic analysis using parsimony, version 4.0 b10. Sinauer Associates, Sunderland.

Thambugala KM, Hyde KD, Tanaka K, Tian Q et al. 2015 - Towards a natural classification and backbone tree for Lophiostomataceae, Floricolaceae, and Amorosiaceae fam. nov. Fungal Diversity 74, 199-266.

Thompson JD, Gibson TJ, Plewniak F, Jeanmougin F et al. 1997 - The CLUSTAL_X windows interface: flexible strategies for multiple sequence alignment aided by quality analysis tools. Nucleic Acids Research 25, 4876.

Toh YF, Yew SM, Chan CL, Na SL et al. 2016 - Genome anatomy of Pyrenochaeta unguishominis UM 256, a multidrug resistant strain isolated from skin scraping. PLoS One 14, 11.

Tulasne LR, Tulasne C. 1863 - Selecta Fungorum Carpologia, vol. 2, 319 pages, 34 Pl. Paris.

Vilgalys R, Hester M. 1990 - Rapid genetic identification and mapping of enzymatically amplified ribosomal DNA from several Cryptococcus species. Journal of Bacteriology 172, 42384246.

White TJ, Bruns T, Lee S, Taylor J. 1990 - Amplification and direct sequencing of fungal ribosomal RNA genes for phylogenetics. In: Innis MA, Gelfand DH, Sninsky JJ, White TJ (eds) PCR protocols: a guide to methods and applications. Academic Press, San Diego, pp. 315-322.

Wijayawardene NN, Crous PW, Kirk PM, Hawksworth DL et al. 2014 - Naming and outline of Dothideomycetes-2014 including proposals. Fungal Diversity 69, 1-55.

Wijayawardene NN, McKenzie EHC, Hyde KD. 2012 - Towards incorporating anamorphic fungi in a natural classification checklist and notes for 2011. Mycosphere 3, 157-228.

Winter G. 1885 - Pilze - Ascomyceten. in: GL Rabenhorst's Kryptogamen- Flora von Deutschland, Oesterreich und der Schweiz. 1, 65-528.

Wu ZH, Wang TH, Huang W, Qu YB. 2001 - A simplified method for chromosome DNA preparation from filamentous fungi. Mycosystema 20, 575-577.

Zhaxybayeva O, Gogarten JP. 2002 - Bootstrap, Bayesian probability and maximum likelihood mapping: exploring new tools for comparative genome analyses 